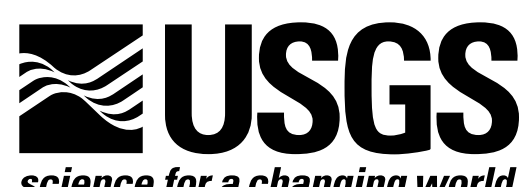

science for a changing world

\title{
Cobalt Mineral Exploration and Supply From 1995 Through 2013
}

Scientific Investigations Report 2011-5084 
THIS PAGE INTENTIONALLY LEFT BLANK 


\section{Cobalt Mineral Exploration and Supply From 1995 Through 2013}

By David R. Wilburn

Scientific Investigations Report 2011-5084 


\section{U.S. Department of the Interior \\ KEN SALAZAR, Secretary \\ U.S. Geological Survey \\ Marcia K. McNutt, Director}

U.S. Geological Survey, Reston, Virginia: 2012

For more information on the USGS - the Federal source for science about the Earth, its natural and living resources, natural hazards, and the environment, visit http://www.usgs.gov or call 1-888-ASK-USGS.

For an overview of USGS information products, including maps, imagery, and publications, visit http://www.usgs.gov/pubprod

To order this and other USGS information products, visit http://store.usgs.gov

Any use of trade, product, or firm names is for descriptive purposes only and does not imply endorsement by the U.S. Government.

Although this report is in the public domain, permission must be secured from the individual copyright owners to reproduce any copyrighted materials contained within this report. 


\section{Contents}

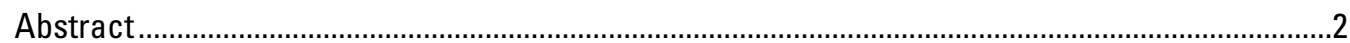

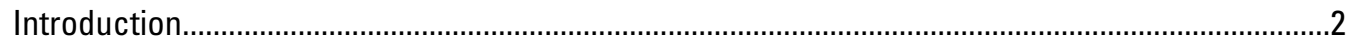

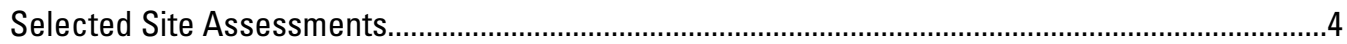

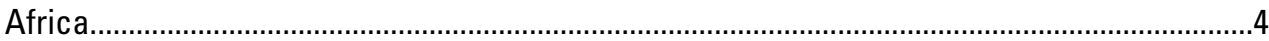

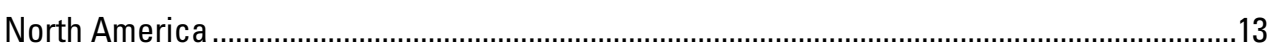

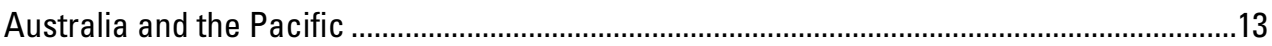

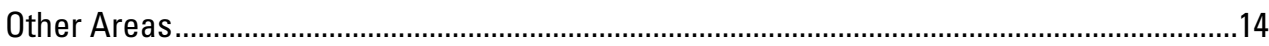

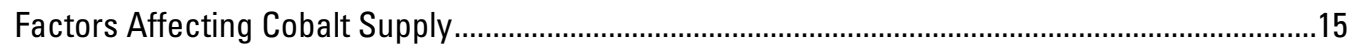

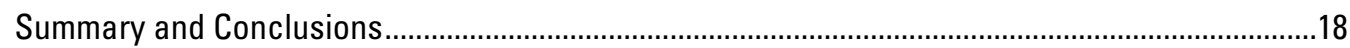

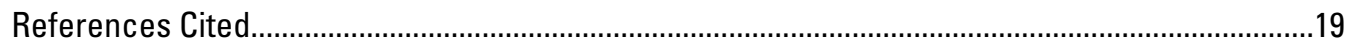

\section{Figures}

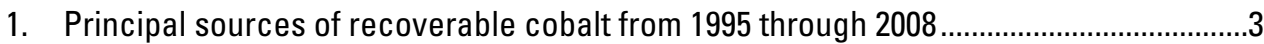

2. Estimated cobalt mine and refinery production and associated refinery capacity of copper-cobalt operations in Congo (Kinshasa) from 1995 through 2007 .....................10

3. Percentage of total cobalt supply from selected new or expanding mines from 1995 through 2008.

4. Anticipated new cobalt capacity from 2009 through 2013 from selected sites attributed to principal commodity 16

5. Anticipated new cobalt capacity from 2009 through 2013 from selected sites by region

\section{Tables}

1. Sites that were included in the statistical analysis .......................................................

2. Sites that were excluded from the statistical analysis .....................................................

3. Chinese participation in sites that were included in the statistical analysis ....................

\section{Conversion Factors}

\begin{tabular}{ccc}
\hline Multiply & By & To obtain \\
\hline & Mass & \\
\hline pound, avoirdupois (lb) & 0.4536 & kilogram $(\mathrm{kg})$ \\
\hline
\end{tabular}

\section{Acronyms}

$\begin{array}{ll}\text { Congo (Kinshasa) } & \text { Democratic Republic of the Congo } \\ \text { Gécamines } & \text { La Générale des Carrières et des Mines } \\ \text { KOV } & \text { Kamoto-Oliveira-Virgule } \\ \text { USGS } & \text { U.S. Geological Survey }\end{array}$


THIS PAGE INTENTIONALLY LEFT BLANK 


\title{
Cobalt Mineral Exploration and Supply From 1995 Through 2013
}

\author{
By David R. Wilburn
}

\section{Abstract}

The global mining industry has invested a large amount of capital in mineral exploration and development over the past 15 years in an effort to ensure that sufficient resources are available to meet future increases in demand for minerals. Exploration data have been used to identify specific sites where this investment has led to a significant contribution in global mineral supply of cobalt or where a significant increase in cobalt production capacity is anticipated in the next 5 years. This report provides an overview of the cobalt industry, factors affecting mineral supply, and circumstances surrounding the development, or lack thereof, of key mineral properties with the potential to affect mineral supply. Of the 48 sites with an effective production capacity of at least 1,000 metric tons per year of cobalt considered for this study, 3 producing sites underwent significant expansion during the study period, 10 exploration sites commenced production from 1995 through 2008, and 16 sites were expected to begin production by 2013 if planned development schedules are met.

Cobalt supply is influenced by economic, environmental, political, and technological factors affecting exploration for and production of copper, nickel, and other metals as well as factors affecting the cobalt industry. Cobalt-rich nickel laterite deposits were discovered and developed in Australia and the South Pacific and improvements in laterite processing technology took place during the 1990s and early in the first decade of the 21 st century when mining of copper-cobalt deposits in Congo (Kinshasa) was restricted because of regional conflict and lack of investment in that country's mining sector. There was also increased exploration for and greater importance placed on cobalt as a byproduct of nickel mining in Australia and Canada. The emergence of China as a major refined cobalt producer and consumer since 2007 has changed the pattern of demand for cobalt, particularly from Africa and Australasia. Chinese companies are increasingly becoming involved in copper and cobalt exploration and mining in Congo (Kinshasa) and Zambia as well as nickel, copper, and other mining in Australia and the South Pacific. Between 2009 and 2013, mines with a cumulative capacity of more than 100,000 metric tons per year of cobalt were proposed to come into production if all sites came into production as scheduled. This additional capacity corresponds to 175 percent of the 2008 global refinery production level. About 45 percent of this cobalt would be from primary nickel deposits, about 32 percent from primary copper deposits, and about 21 percent from primary cobalt deposits. By 2013, about 40 percent of new capacity was expected to come from the
African Copperbelt; 38 percent, from Australia and the South Pacific countries of Philippines, Indonesia, New Caledonia, and Papua New Guinea; 11 percent, from other African countries; 5 percent, from North America; and 6 percent, from other areas.

\section{Introduction}

An adequate and dependable supply of minerals and materials is essential to meet the goals and economic requirements of the United States. The U.S. Geological Survey (USGS) actively monitors global nonfuel mineral exploration and development activities to better anticipate the location and quantity of future supplies of minerals. Data collected from this activity have been used to identify the specific circumstances where recent exploration has supported the development of new or expanded capacity for selected mineral commodities or where a significant increase in mineral production capacity is anticipated by 2013.

This report focuses on the development of expanded, new, or rehabilitated mineral production capacity derived from selected sites where significant exploration activity has occurred since 1995. Discussions include factors affecting changes in mineral supply patterns and circumstances surrounding the development, or lack thereof, of mineral properties with the potential to significantly affect mineral supply. Cobalt was selected for this assessment because of its strategic importance to the Nation, the import dependence of the United States for cobalt, and the changing supply patterns relative to the commodity's dependence on the production of other mineral commodities, such as copper and nickel. Sites with a likely production capacity of at least 1,000 metric tons per year $(\mathrm{t} / \mathrm{yr})$ of cobalt were evaluated in this assessment or where cobalt was a significant byproduct of a mine with a capacity greater than 40,000 t/yr of copper or $15,000 \mathrm{t} / \mathrm{yr}$ of nickel. Production capacity estimates and development schedules were based on recent estimates provided by company, industry, and government sources.

Cobalt is a strategic metal used in many diverse commercial, industrial, and military applications. Except for a small amount of byproduct cobalt produced as intermediate products from mining operations, the U.S. mineral industry did not mine or refine cobalt from domestic sources in 2008, when about 81 percent of U.S. cobalt supply came from imports and U.S. stock releases of primary cobalt and about 19 percent was recovered from domestic and imported scrap (Shedd, 2010a). 
Consequently, the United States is predominately import dependent for cobalt. Although cobalt is widespread in the Earth's crust, it is normally found in concentrations insufficient to justify large-scale economic recovery by itself. Exceptions include the mining of heterogenite deposits in Congo (Kinshasa) and cobalt and arsenic deposits in Morocco. At prevailing prices in early 2009, the cost of production from most U.S. depositsas a byproduct or as the sole product of a mining operationwas higher than the market price for cobalt (MetalMiner, 2009).

Cobalt is traditionally produced as a byproduct of another metal, such as copper, nickel, or precious metals. The largest cobalt reserves occur in the Copperbelt of Congo (Kinshasa) and Zambia, as well as in Australia and Cuba (Shedd, 2010b). Because cobalt most often is found in association with copper and nickel, geologic provinces containing anomalously high cobalt values generally are well explored. The amount and principal locations from which cobalt was mined and (or) recovered as a byproduct of metal mining from 1995 through 2008 are shown in figure 1 . In 2008, about 50 percent of refined cobalt production was derived from deposits where nickel was the primary commodity; 35 percent, where copper was the primary commodity; and 15 percent, where cobalt was the principal product recovered from mining operations, metal scrap, and slag (Cobalt Development Institute, 2008). Production of recoverable cobalt has almost tripled from 1995 through 2008 (fig. 1) because of increased demand for cobalt in rechargeable batteries and superalloys associated with aerospace and gas turbine applications. Much of the increased production that occurred in Congo (Kinshasa) during this time was largely a result of the cessation of regional conflict, leading to an increase in nontraditional artisanal mining of heterogenite ore after 1999. From 1995 through 2008, cobalt production from Congo (Kinshasa) has increased from 7 percent to 41 percent of world cobalt production, with corresponding decreases during this period from Zambia (24 percent down to 9 percent), Canada (22 percent down to 11 percent), and Russia (14 percent down to 8 percent). Although China has increased refined cobalt production capacity during this period from about 1 percent to about 31 percent of world capacity, its share of mined cobalt production has remained less than 9 percent (Shedd, 1999-2010). Consequently, China relies on imported sources of cobalt in various forms of concentrate and intermediate products.

Assessment of the effect of exploration on future supply is made more difficult by the uncertainty resulting from the weakened global economy that began in late 2008 and which

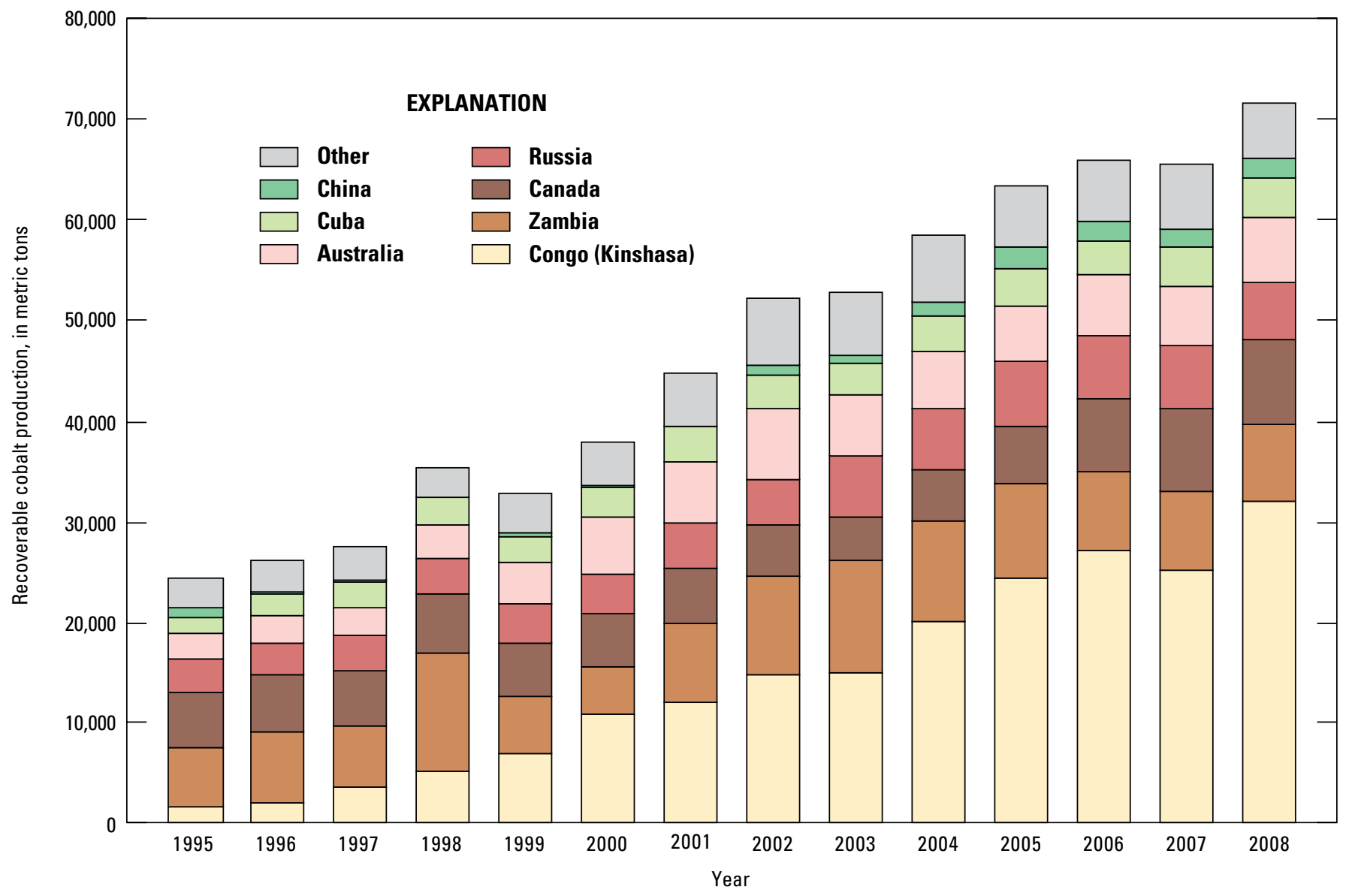

Figure 1. Principal sources of recoverable cobalt from 1995 through 2008. Chart represents recoverable cobalt content of ores, concentrates, intermediate products, or refined cobalt produced from cobalt, copper, nickel, platinum, or zinc operations. Source: U.S. Geological Survey, Minerals Yearbook series, various authors and various years. 
has reduced global demand for many metals, resulted in lower production of cobalt and (or) associated metals, and curtailed or reduced development of new capacity. The price of cobalt, which reached \$54 per pound in March 2008, dropped below $\$ 13$ per pound in December 2008, a level last seen in early 2006 (Shedd, 2009a,b). Similarly, the price of copper exceeded $\$ 4$ per pound in July 2008 , but dropped to about $\$ 1.30$ per pound by the end of December 2008, and the price of nickel dropped from about \$33 per metric ton in March 2008 to less than \$10 per ton in December (MetalPrices.com, 2009). As a result, many previously announced mine developments and expansions were suspended, scaled back, or delayed until such time as market prices could justify further investment or capital expenditure. A few projects have maintained their development schedules to meet construction or supply obligations. Future shortterm development plans for many operations have not been announced or are still to be determined, although metal prices have rebounded somewhat since December 2008. For example, as of May 2010, the price of cobalt was about $\$ 22$ per pound, the price of copper was about $\$ 3.10$ per pound, and the price of nickel was about $\$ 10$ per pound. Development schedules used in this analysis reflect public information reported as of May 2010. Development decisions made after this date were not considered in this analysis.

\section{Selected Site Assessments}

This report focuses on selected sites where mineral exploration since 1995 has led to the development of a mine with production capacity greater than $1,000 \mathrm{t} / \mathrm{yr}$ of contained cobalt in ore as primary cobalt or as a byproduct of a deposit with capacity exceeding 40,000 t/yr of contained copper or $15,000 \mathrm{t} / \mathrm{yr}$ of contained nickel in ore or recoverable product. The cobalt capacity cutoff of $1,000 \mathrm{t} / \mathrm{yr}$ represents about 2 percent of the total average annual recovery of cobalt from mining operations from 1995 through 2008. Table 1 lists all sites that met the capacity cutoff criteria; an explanation was provided for each of the sites that were excluded from the statistical analysis (table 2). Of the 48 sites that meet these capacity requirements, 5 are sites that were producing prior to the study period with no significant expansion derived from new exploration, so these were not included in the statistical analysis. Because of positive exploration results, the production capacity of 3 producing sites was expanded from 1995 through 2008, 10 sites initiated production during this period, and 16 are planned to begin production by 2013 . A total of 14 additional sites met the criteria, but initial production was pushed beyond 2013; therefore, these sites were not considered for the statistical analysis in this report. Information related to the various stages of development (year of initial discovery, date of feasibility study, commencement of construction, and first year of production) are provided in table 1 , where available.

\section{Africa}

Because the world is dependent for much of its cobalt from cobalt and copper mining in what is now called the
Democratic Republic of the Congo [Congo (Kinshasa)], changes in the structure of the country's cobalt and copper mining and processing industry since 1995 have had a global effect. Much of the existing cobalt capacity in the country during the 1980s was controlled by La Générale des Carrières et des Mines (Gécamines), the state-owned mining company, by means of direct ownership or operating agreements with private companies. During the 1980 s, about 54 percent of world's cobalt mine output was from copper and cobalt mining in the country. By 1995, copper production had declined to about 5 percent of the 1985 peak level, and associated cobalt production had declined to about 6 percent of the 1985 production level (U.S. Geological Survey, Minerals Yearbook series, various authors and various years), primarily because of the lack of reinvestment capital in mining operations and shortages of equipment, fuel, and parts (International Monetary Fund, 2005, p. 47). Civil unrest between 1996 and 2002 added to the difficulties associated with exploration, mining, and processing in the country, and by 1998, most foreign exploration activity and development-oriented feasibility work had ceased (Coakley, 2003). With the end of countrywide civil unrest, the establishment of a more stable government, and the passage of a new mining law promoting mineral development by the private sector in 2002 , foreign investors gradually began reevaluating existing joint-venture agreements and expanded mineral exploration activities. However, the decay of the industry and civil unrest had destroyed much of the existing mining infrastructure. The need for extensive rehabilitation in the mining operations resulted in the copper-cobalt concentrate being processed outside of Congo (Kinshasa). The effective mining capacity in Congo (Kinshasa) from 1996 through 2001 was estimated to be less than 10 percent of the original design capacity (Coakley, 2004).

Estimating the effective mine capacity for cobalt in Congo (Kinshasa) is difficult because of the byproduct status of cobalt and because the capacities of most mines under direct control of Gécamines continue to be reported at 1985 levels, even though the company's production is inhibited by aging equipment; a lack of investment, fuel, and spare parts; and poor infrastructure (Yager, 2008). About 17,500 metric tons $(\mathrm{t})$ of cobalt was reportedly recovered in 2008 , whereas the aggregated effective cobalt mine capacity for all active mines in Congo (Kinshasa) was reported to be 26,800 $\mathrm{t}$ (Yager, 2010). Therefore, the capacity utilization rate for 2008 would be about 65.5 percent. But this estimate does not include the Gécamines operations that are not under jointventure agreements or the artisanal and small-scale mining of cobalt-producing deposits, which played a significant role in the country's cobalt mine production (Yager, 2009). When all cobalt-producing mines are taken into account, and assuming that Gécamines was operating its mines as close as possible to effective capacity during the high copper and cobalt prices of 2006-08, the estimated effective mine capacity utilization rate for all cobalt-producing mines in Congo (Kinshasa), including Gécamines, was 22 percent in 2008 (Yager, 2010). Many of the new or rehabilitated mines in Congo (Kinshasa), however, had not achieved their design capacity in 2008.

Exploration for copper deposits containing cobalt in Congo (Kinshasa) has been centered on the reevaluation and redevelopment of past mining centers (known as brownfield exploration sites), as well as identification and development 


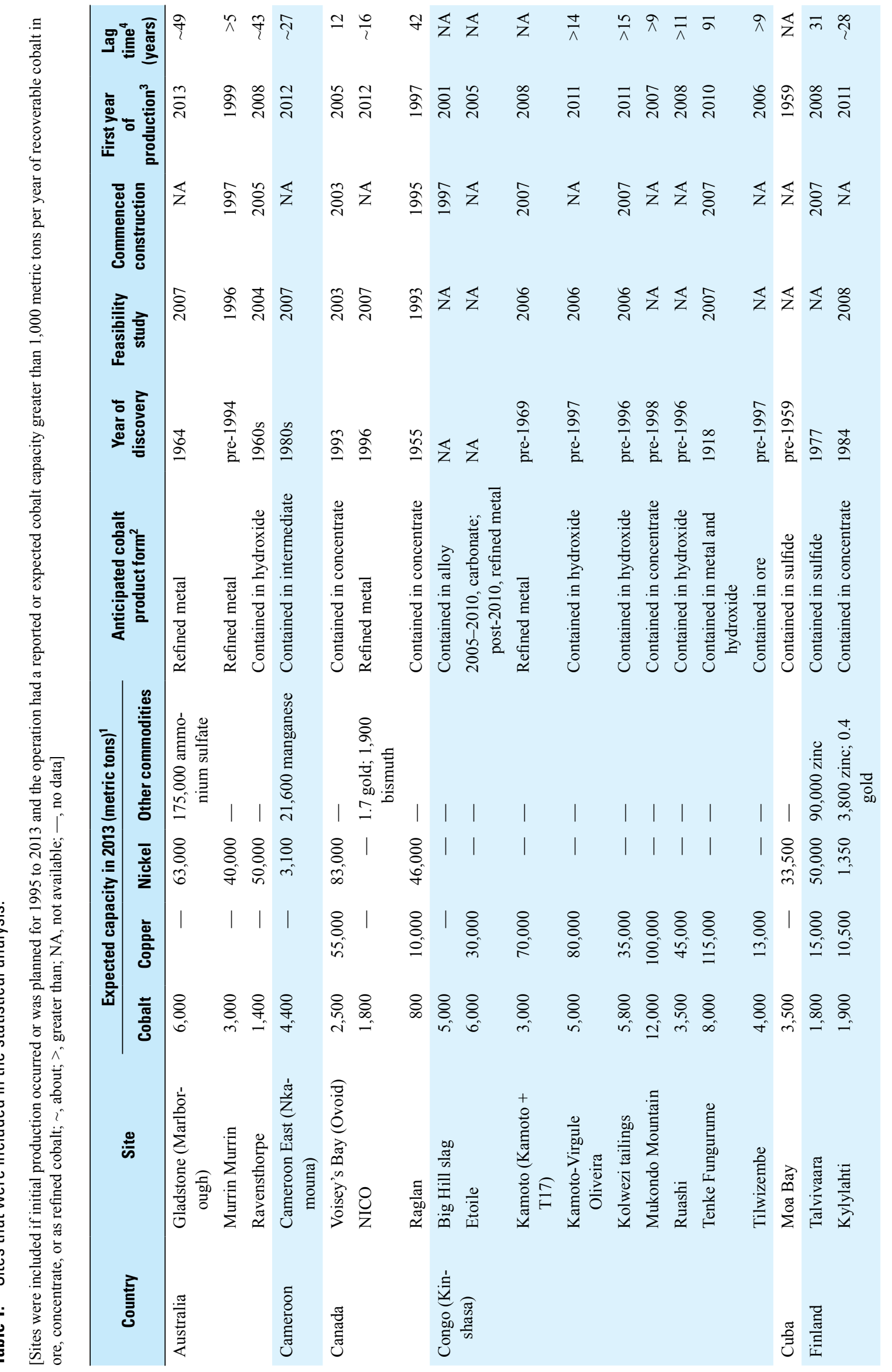




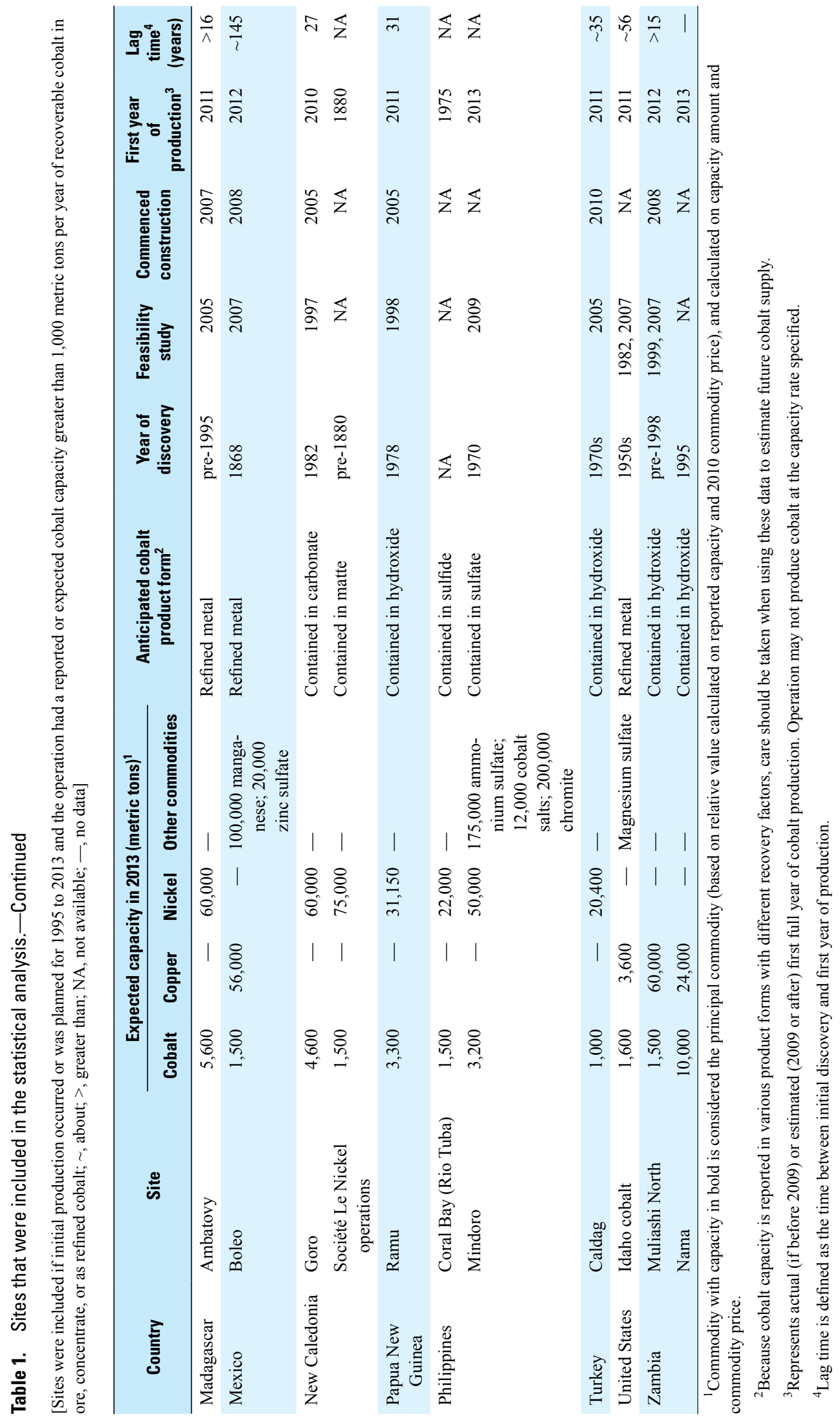


Table 2. Sites that were excluded from the statistical analysis.

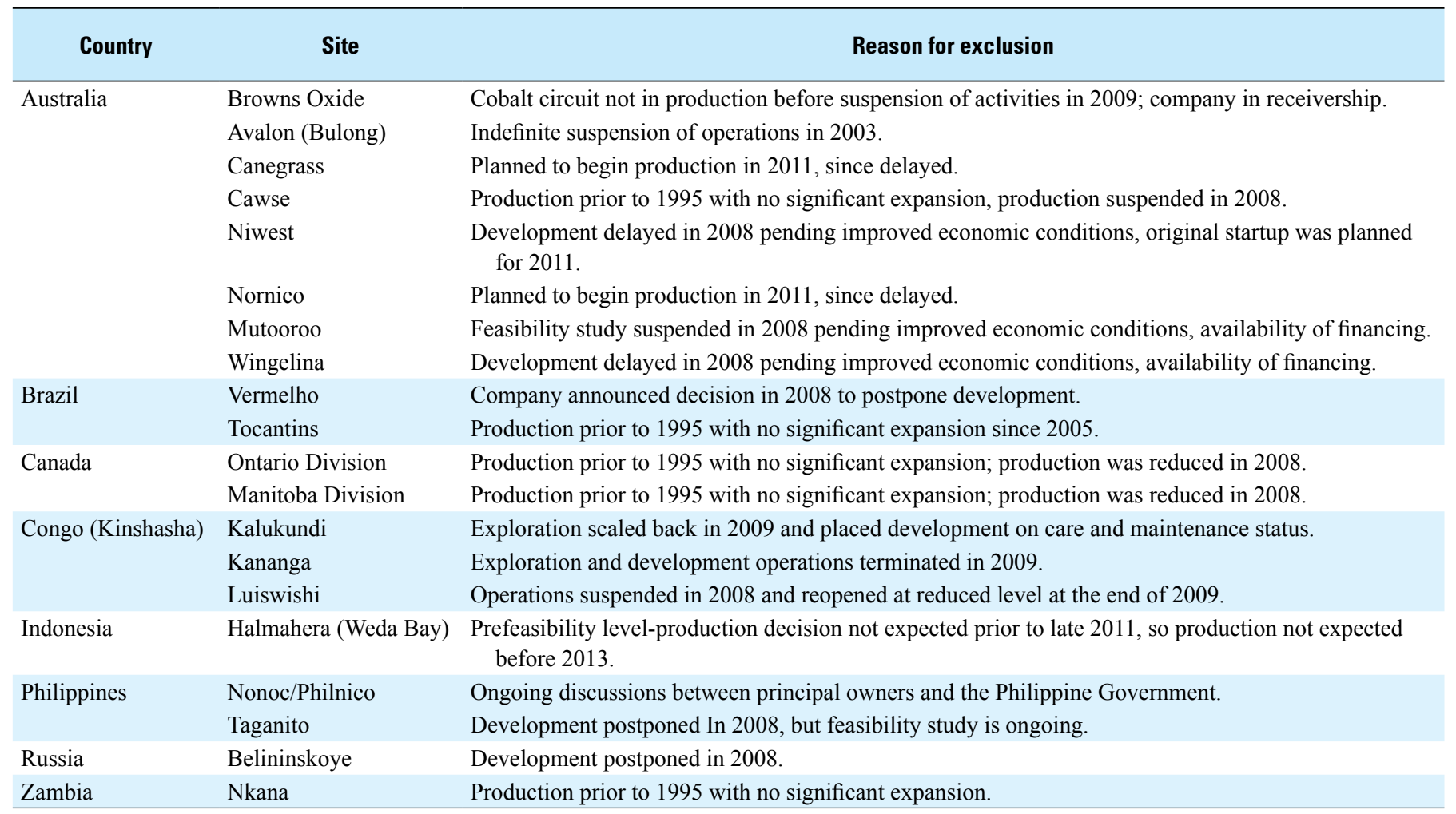

of newly discovered or previously undeveloped deposits (greenfield exploration sites). Foreign investment allowed the refurbished Luiswishi copper-cobalt mine to reach its capacity of 4,500 t/yr of cobalt contained in concentrate in 2002 (George Forrest International S.A., 2007) and provided development funding for the Big Hill slag reprocessing operation, which was operating at 80 percent of its capacity of 5,000 t/yr of cobalt contained in concentrate in 2001 (Yager, 2009).

From 2002 through 2006, exploration drilling defined resources sufficient to support the refurbishment of several brownfield sites, each capable of producing more than 1,000 t/yr of cobalt. Mining of the Tilwezembe copper-cobalt deposit has taken place intermittently since 1999 by artisanal and contract miners until 2006, when Nikanor plc began an operation with an initial capacity of 4,000 t/yr of cobalt contained in ore (Katanga Mining Limited, 2009, p. 43; Yager, 2009). Gécamines similarly conducted intermittent contract mining of the Kananga coppercobalt deposit from 2004 until Nikanor plc took control of the site in 2006 and planned to operate the site with capacity of 7,000 t/yr of cobalt contained in ore (Katanga Mining Limited, 2009, p. 44; Yager 2009). Mining at the Kananga operations was operated by artisanal miners after 2007 and operations at Tilwezembe ceased in 2008 after ownership restructuring driven by lower metals prices. Metorex Limited began mining copper-cobalt tailings from the Ruashi mine with a capacity of 1,000 t/yr of cobalt contained in concentrate in early 2007 and immediately announced plans to fast-track development of a phase 2 expansion of mining and concentrate processing facilities to produce up to 3,500 $\mathrm{t} / \mathrm{yr}$ of cobalt contained in cobalt hydroxide by 2010 (Metorex Limited, 2009). Technical problems and the drop in cobalt and copper demand from 2008 through 2009 have resulted in the Ruashi facility producing at a level below capacity. Refurbishment of Katanga Mining Limited's Kamoto complex (Kamoto underground mine and T17 open pit mine) was completed in 2007 , and the coppercobalt operation achieved capacities of 70,000 t/yr of copper and 3,000 t/yr of refined cobalt in 2009 (Katanga Mining Limited, 2008, p. 21).

Exploration since 1996 provided the base data from which the Mukondo Mountain and associated copper-cobalt deposits were developed; the mine (with initial capacity of $8,000 \mathrm{t} / \mathrm{yr}$ of cobalt contained in concentrate) commenced production in late 2007 but suspended operations from November 2008 through March 2009 as a result of depressed metal markets (Central African Mining and Exploration Company, 2009a,b). The mine resumed production in 2009 and was scheduled to reach a capacity of $8,000 \mathrm{t} / \mathrm{yr}$ of concentrate, including 3,200 t/yr of cobalt that could be processed to carbonate by 2010 (Central African Mining and Exploration Company, 2009a). If demand were to justify the cost of additional expansion, the site could raise its production to $12,000 \mathrm{t} / \mathrm{yr}$ of cobalt by 2012 .

A second greenfield development project is the Tenke Fungurume operation. Although the deposit has been known for decades, development has been slowed by lack of investment, legal hurdles, ownership changes, and regional unrest. The Tenke Fungurume copper-cobalt project began initial copper production in 2009 and cobalt recovery began in late 2009 with toll treatment at the Chambishi smelter. The facility is designed to produce 8,000 t/yr of cobalt metal and cobalt hydroxide from its concentrate (Freeport-McMoRan Copper \& Gold Incorporated, 2009). 
Other mines with capacities of more than $1,000 \mathrm{t} / \mathrm{yr}$ of recoverable cobalt were expected to be operational in Congo (Kinshasa) by 2013 if conditions warrant. Development of the Kolwezi project, which was designed to process tailings generated by the Kolwezi concentrator, was ongoing. As planned, the project would produce up to 7,000 $\mathrm{t} / \mathrm{yr}$ of cobalt hydroxide $(5,800 \mathrm{t} / \mathrm{yr}$ of cobalt), with initial production scheduled for 2011 (First Quantum Minerals Limited, 2008). Dewatering of the Kamoto-Oliveira-Virgule (KOV) open pit began in 2008 and continued into 2009; initial production from the KOV mine was planned for late 2010. The Kamoto concentrator, which would receive ore from the Kamoto complex and the KOV mine, was expected to reach its capacity of 150,000 t/yr of copper and 8,000 t/yr of refined cobalt by mid-2011 (Hill, 2009; Katanga Mining Limited, 2009, p. 159). The Etoile copper-cobalt mine, with current capacity of 3,300 t/yr of cobalt in carbonate, planned to add processing capacity to produce $6,000 \mathrm{t} / \mathrm{yr}$ of refined cobalt in 2009 , but recent reports suggested that this expansion may have been delayed.

Estimates of cobalt mine and refinery production from Congo (Kinshasa) from 1995 through 2008, along with estimates of associated refinery capacity, are shown in figure 2 . Mine production calculations represent estimated recoverable cobalt content of ores, concentrates, tailings, and slags, or intermediate products from cobalt and copper operations. Mine production calculations from 1995 through 2000 did not include stockpiled materials that were processed at the refineries during that period; cobalt recovered from artisanal mining prior to 2000 was also excluded. The difference between mine production and refinery production calculations after 1999 (expressed in contained cobalt content) reflect, in part, the increasing amount of cobalt-containing material that is being exported, primarily to China and India; the increasing amount of artisanal mining for cobalt in Congo (Kinshasa); the increasing demand for cobalt by Asian companies as a component of rechargeable batteries; and the deterioration of infrastructure associated with the refineries in Congo (Shedd, 1999-2010).

Cobalt trade between China and Congo (Kinshasa) has increased significantly during the past decade. Chinese interests have established supply contracts for Congolese cobalt products and acquired interest in several coppercobalt processing facilities in Congo (Kinshasa). Chinese companies also are involved in the development of several new copper-cobalt mines, smelters, and hydromet plants (for making cobalt carbonate) in Congo (Kinshasa). Chinese involvement in sites considered for this analysis is listed in table 3. Chinese companies are reported to be involved with many smaller artisanal mining projects and downstream processing operations. For example, reports suggest that 40 Chinese companies ceased operations at the end of 2008 at copper smelters in Katanga Province because of the economic downturn. This move resulted in increased uncertainty about the reliability of copper-cobalt supply from both established and artisanal mining operations.

In 2007, the Government of Congo (Kinshasa) imposed a ban on the export of unprocessed cobalt ores and, for a period of time, cobalt concentrates (Shedd, 2009). Because much of

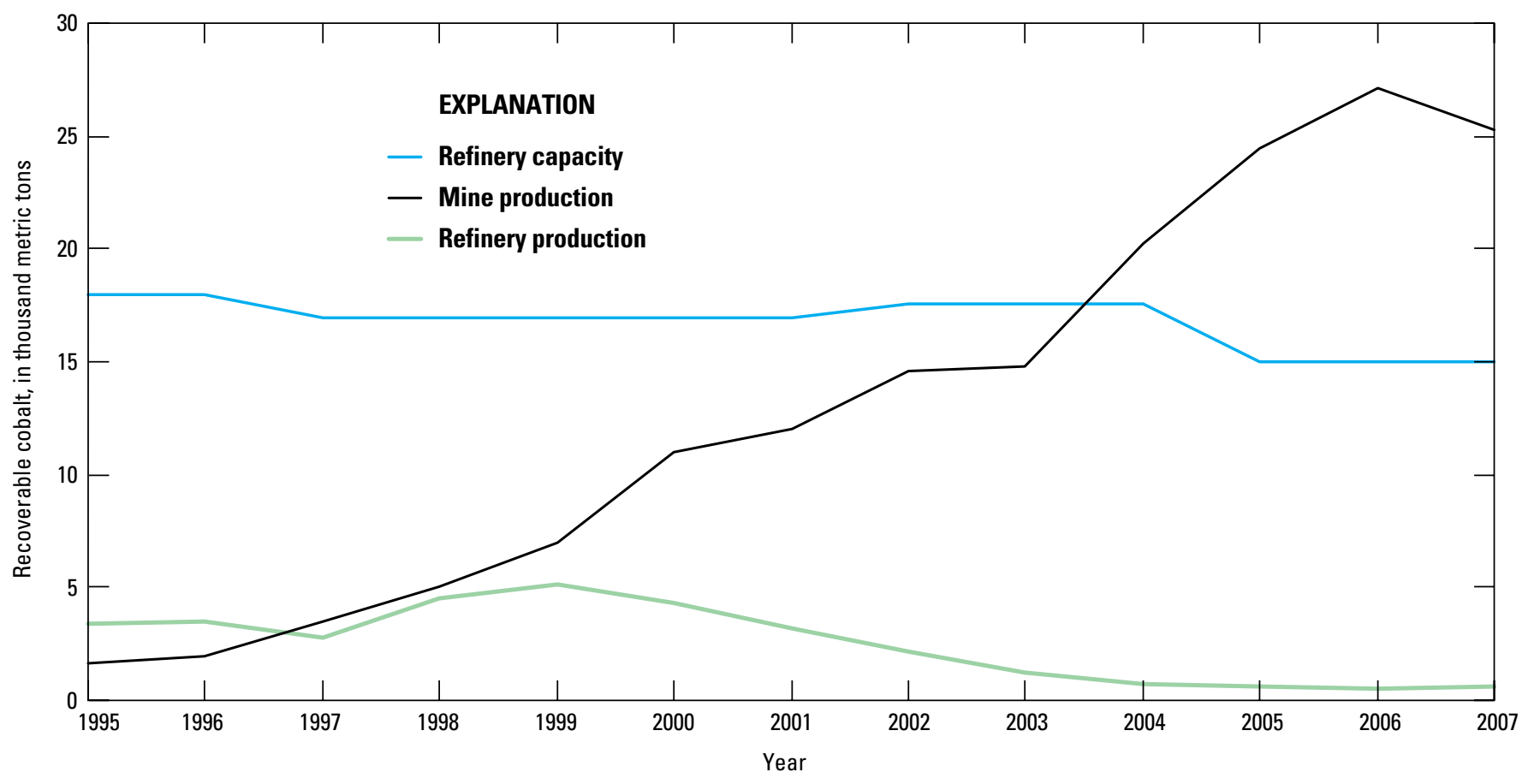

Figure 2. Estimated cobalt mine and refinery production and associated refinery capacity of copper-cobalt operations in Congo (Kinshasa) from 1995 through 2007. Graph represents recoverable cobalt content of ores, concentrates, or intermediate products from cobalt and copper operations. Mine capacity estimates are not available for the entire study period. Mine source: U.S. Geological
Survey, Minerals Yearbook series, various authors and various years. Production calculations from 1995 through 2000 do not include stockpiled materials that were processed at the refineries during the period. Cobalt recovered from artisanal mining operations have been included in the mine production calculations after 1999. Much of this material is exported, primarily to China and India. 


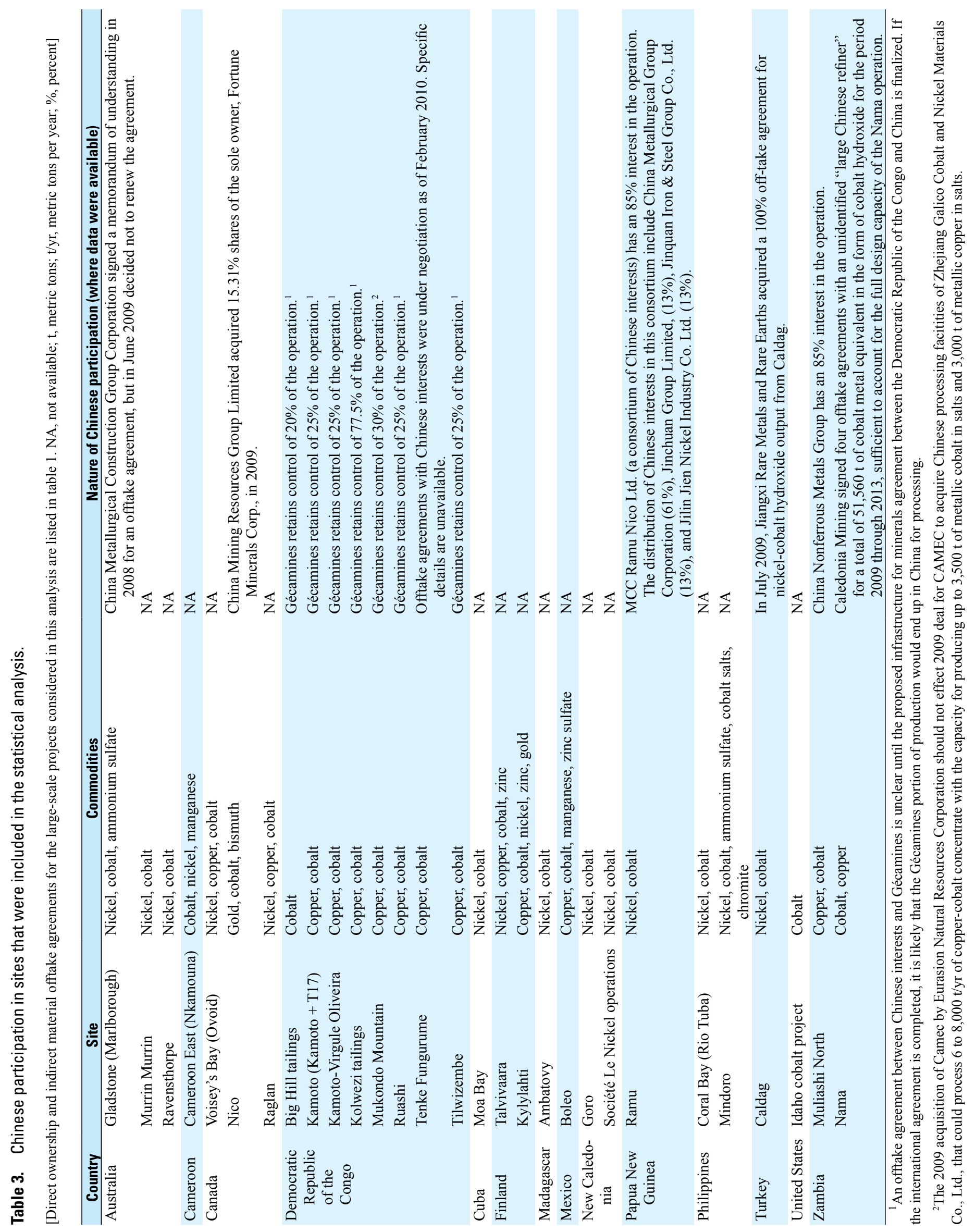


this material was normally exported to China for processing, production of cobalt refined in China from African sources in 2007 was significantly reduced until the ban was lifted. Production of cobalt refined in China rebounded in 2008, with a reported 38 percent increase in production "as a result of bigger shipments of concentrate and cobalt containing intermediates imported into China from Congo (Kinshasa) during the year" (Hill, 2009). Also in 2008, China and Congo (Kinshasa) signed a $\$ 9$ billion agreement in which China would finance the construction of $\$ 6$ billion worth of infrastructure in exchange for a guaranteed supply of 10 million metric tons of copper and $400,000 \mathrm{t}$ of cobalt (Whewell, 2008). Details of the agreement were still being finalized. The final terms of this agreement will likely affect the amount of material that the state-owned mining company Gécamines and other companies produce and export. Uncertainty surrounding the trade agreement will also affect the development on mines dependent upon hydroelectric power plants Chinese investment groups agreed to fund as part of this agreement. For example, the joint venture among Chinese interests created to expand the Kamoto and KOV projects would increasingly rely on such infrastructure. Projects still in feasibility or early development stages, such as the Tenke-Fungurume project, would also depend upon adequate hydroelectric power that Chinese investment groups would construct and supply.

Cobalt capacity from mines in Zambia could increase by up to $6,500 \mathrm{t} / \mathrm{yr}$ of contained cobalt if the Muliashi North and Nama projects reach targeted capacity levels by 2013 . The Muliashi North copper-cobalt project was planned to produce 1,500 t/yr of contained cobalt after 2010 (Reuters, 2009). A prefeasibility study conducted in 2008 for the Nama cobalt-copper-nickel project estimated that a mine with a contained cobalt capacity of 10,000 $\mathrm{t} / \mathrm{yr}$ of cobalt contained in ore could be in production by 2009 ; however, the operation continued to experience technical delays, and proposed changes in taxation could delay development beyond 2013 (Caledonia Mining Corporation, 2008).

The Ambatovy nickel-cobalt laterite project in Madagascar and the Nkamouna cobalt-nickel laterite project in Cameroon are two other African projects that could contribute to increased cobalt capacity within the next 5 years. Extensive exploration in the mid-1990s provided data supporting the 2005 decision to develop the Ambatovy project. Construction began in 2007, but development plans were being reevaluated in 2009 in light of current economic conditions. Reported plans called for a late 2010 startup with a reported production capacity of 5,600 t/yr recoverable cobalt metal (Sherritt International Corporation, 2009b). The Nkamouma project had also been delayed because of economic conditions, but it was likely to be developed from 2012 through 2013. A feasibility study completed in 2008 showed annual production reaching 4,400 t of cobalt contained in intermediate products (Geovic Mining Corporation, 2009). Should these two projects develop as was anticipated, their combined capacity would be equivalent to 17 percent of the 2008 global refinery production level of 57,600 t/yr (Shedd, 2010).

\section{North America}

The production of cobalt from Canada increased in 2006 with the commencement of mining of the Voisey's Bay nickelcopper-cobalt deposit in Labrador. At full capacity, this mine is capable of producing 2,500 t/yr of byproduct cobalt contained in concentrates (Companhia Vale do Rio Doce, 2009a). The deposit was initially discovered in 1993, and exploration quickly established its economic potential, but development was delayed because of native title claims, ownership issues, and disagreement between operators and the provincial government of Newfoundland and Labrador over the location of associated smelting and refining facilities. After 4 years of delay, construction started in 2003, and mining commenced in 2005. In 2008, the mine produced 1,695 t of cobalt, 56,000 $\mathrm{t}$ of copper, and 83,500 $\mathrm{t}$ of nickel contained in concentrate, which was smelted and refined offsite (Companhia Vale do Rio Doce, 2009a). Based on an agreement with the Province of Newfoundland and Labrador, the company is required to construct a processing plant designed to produce 2,500 t/yr of cobalt, 55,000 t/yr of copper, and 50,000 t/yr of nickel by 2013 (Companhia Vale do Rio Doce, 2009a). The Voisey's Bay mine accounted for about 20 percent of Canadian cobalt production and 2.4 percent of global cobalt production in 2008. This is significant because the mine would not have been constructed for its cobalt values alone.

A second mine that contributed significantly to Canadian cobalt production is the Raglan mine in Quebec, a nickelcopper-cobalt-platinum-group metal deposit that commenced production at the end of 1997. Cobalt occurs in association with nickel-copper sulfides. Byproduct cobalt production of about $300 \mathrm{t}$ of cobalt contained in concentrate was produced each year from 1997 through 2000, about 400 t of contained cobalt was produced each year from 2001 through 2003, and a capacity expansion to $525 \mathrm{t} / \mathrm{yr}$ of contained cobalt was achieved in 2007. A further expansion to an estimated $800 \mathrm{t} / \mathrm{yr}$ of contained cobalt was envisioned by 2011, when economic conditions permit (Xstrata plc, 2007). Based on 2008 production, the Raglan mine accounted for about 6.2 percent of Canadian cobalt production or 0.7 percent of world cobalt production.

The NICO gold-cobalt-bismuth-copper project in the Northwest Territories of Canada, discovered in 1996, has reached the permitting and environmental assessment stage of development; a feasibility study conducted in 2007 and updated in 2008 was based on developing a mine and facility that will produce cobalt metal or cobalt carbonate products containing 1,800 t/yr of cobalt from a concentrate by the end of 2012 (Fortune Minerals Limited, 2009).

The Moa Bay nickel-cobalt mine in Cuba has been the principal producer of cobalt in Cuba since 1959. Sherritt International Corporation completed a phase 1 expansion of the operation in 2008 that increased capacity to $33,500 \mathrm{t} / \mathrm{yr}$ of copper and 3,500 t/yr of cobalt. The company cited market conditions as the reason for the postponement of the planned phase 2 expansion to 49,000 t/yr of copper and 4,300 t/yr of cobalt (Sherritt International Corporation, 2009a, p. 6, 63).

The Boleo polymetallic deposit in Mexico was discovered in 1868 and mined sporadically from 1886 through 1947 and from 1968 through 1985. Exploration of the area in the 1990s renewed interest in the project. A prefeasibility study was conducted in 1998, and a feasibility study was completed in 2007. Development was approved in 2008, and preconstruction activities began. Initial production was originally targeted for 2010; the development schedule was being reassessed in 2009 as a result of market conditions and investment by a Republic of Korea consortium. The 
2007 feasibility study was based on developing a facility with a cobalt capacity of up to $3,100 \mathrm{t} / \mathrm{yr}$ of cobalt cathode, or an annual average production of 1,500 $t$ of cobalt; the current date of targeted production was 2012 (Baja Mining Corporation, 2010).

The Idaho Cobalt cobalt-copper deposit is considered an extension of the deposit containing the former Blackbird mine in Idaho. Drilling in 1995 indicated newly defined zones of mineralization, and subsequent exploration work formed a basis for a feasibility study completed in 2007. Formation Capital Corporation was in the process of securing permitting and financing to develop an operation capable of producing up to $1,600 \mathrm{t} / \mathrm{yr}$ of cobalt after a 15 -month period of construction. The company planned to begin initial production by the second half of 2010 (Formation Capital Corporation, 2010).

\section{Australia and the Pacific}

Production of cobalt in Australia originates from domestic and imported ores from neighboring Pacific countries. Three mining projects fueled the increase in Australian cobalt capacity from 1995 through 2008. The Murrin Murrin mine and refinery has produced nickel and cobalt since 1999 from laterite deposits discovered in the mid-1990s. The cobalt recovery circuit at Murrin Murrin has averaged about 2,000 t/yr of cobalt, well below its rated capacity of $3,000 \mathrm{t} / \mathrm{yr}$ of refined cobalt since operations began (Glencore International AG, 2009). In 2008, a pilot plant reached design capacity to recover an additional $150 \mathrm{t} / \mathrm{yr}$ of cobalt from stockpiled Murrin Murrin material, but recovery of this material had not been implemented as of early 2010. In 2008, the Murrin Murrin facility accounted for about 32 percent of Australian cobalt and 2.8 percent of worldwide production of cobalt.

The Cawse operation derived its feed from nickel laterite deposits discovered in 1994. The mine and processing plant produced from 1999 through 2008, when it was placed on care-and-maintenance status. After 2002, intermediate nickelcobalt carbonate produced by the Cawse plant was shipped to the Harjavalta refinery in Finland (MMC Norilsk Nickel, 2009). At its peak, the Cawse operation produced more than $1,000 \mathrm{t} / \mathrm{yr}$ of cobalt contained in carbonate, accounting for 18 percent of Australian cobalt production and 2.7 percent of global cobalt production.

Feed for the Ravensthorpe nickel-cobalt plant is supplied from several nickel laterite deposits (including Bandalup Hill, Halley's, Hale Bopp, and Shoemaker-Levy) initially discovered in the 1960s but reevaluated and developed since the mid-1990s. The facility commenced production in late 2007 with a projected capacity of 1,400 t/yr of cobalt contained in a mixed hydroxide intermediate product (BHP Billiton Limited, 2008). Before this production rate could be achieved, however, economic conditions resulted in the suspension of this operation in early 2009.

The Browns polymetallic deposits were identified in the early 1960 s, but exploration to delineate the ore occurred during the 1990s. Limited production of the Browns oxide deposit began in late 2008, but legal and economic problems forced the cessation of activities in early 2009. Projected cobalt capacity of this operation was $1,000 \mathrm{t} / \mathrm{yr}$ of cobalt in cobalt-nickel carbonate (Compass Resources NL, 2009).
Based on a feasibility study completed in 2007, the Gladstone nickel-cobalt laterite project in Australia may contribute more than $6,000 \mathrm{t} / \mathrm{yr}$ of recoverable cobalt by 2013. Environmental approval was granted in 2009 , but development was being reviewed in light of current market conditions (Gladstone Pacific Nickel Limited, 2009). Should the stated capacity level be achieved, the 2013 capacity would be equivalent to about 10 percent of the 2008 global refinery production level of $57,600 \mathrm{t} / \mathrm{yr}$.

Eramet SA was mining nickel-cobalt from sites on New Caledonia as part of its Société Le Nickel operations. The company continued to explore the area to find new mineral deposits to feed its Doniambo smelter. In 2003, Eramet began a program to expand capacity from $61,500 \mathrm{t} / \mathrm{yr}$ to $75,000 \mathrm{t} / \mathrm{yr}$ of nickel and an estimated 1,500 t/yr of cobalt in matte (Eramet SA, 2009). If economic conditions permited, it was expected that the expansion would be in operation during 2011.

Several sites in the South Pacific region were planned for cobalt production by 2013. Development of the Goro nickel-cobalt laterite project in New Caledonia, originally discovered in 1982 and extensively explored in the 1990s, was continuing, with a planned production commencement in 2010 and a 4-year gradual increase to full capacity (Companhia Vale do Rio Doce, 2009b). The operation was planned for a full capacity of 4,600 t/yr of cobalt as carbonate. The Ramu nickel-cobalt laterite project in Papua New Guinea, discovered in 1978 and further explored in the 1990s, was also under construction and was scheduled to begin commissioning at the end of 2009 (Highlands Pacific Limited, 2009). Mining and processing at the full capacity of 3,300 t/yr of cobalt contained in an intermediate hydroxide product was anticipated by 2011 .

Cobalt production from four sites in the Philippines was ongoing or planned, but development at two sites was currently being delayed or reassessed. The Coral Bay facility on Palawan Island began production of nickel-cobalt sulfide from the Rio Tuba mine in 2005. An expansion of the facility to $1,500 \mathrm{t} / \mathrm{yr}$ of cobalt in an intermediate product was completed in 2009 (Sumitomo Metal Mining Company, Limited, 2009). A feasibility study was ongoing in 2009 for the Mindoro nickel-cobalt laterite project; initial assessments allowed for up to 3,200 t/yr of cobalt as sulfate with initial production by 2013 (Peterson, 2009). Development of the Nonoc project, with a proposed cobalt production capacity of 3,600 t/yr of contained cobalt, has been delayed since 2006 because of an ownership sharing disagreement between its owner and Chinese interests and a legal dispute over the mineral production sharing agreement. Development of the 2,500 t/yr cobalt Taganito project has been delayed since 2008 by poor market conditions. It is unlikely that the latter two sites would reach full capacity by 2013 .

As with copper-cobalt and nickel operations in Africa, Chinese companies are interested in increasing their involvement in nickel-cobalt development and mining activities in the Pacific region by means of offtake agreements and direct corporate ownership. Chinese interests have evaluated participation in the Browns Oxide, Mutooroo, and Wingellina projects in Australia, the Ramu project in Papua New Guinea, and the Mindoro and Nonoc projects in the Philippines, although Chinese companies that had initially shown interest withdrew from participating in the Mindoro project in 2006, the Nonoc project in 2007, and the Mutooroo project in 2008. 


\section{Other Areas}

The Talvivaara nickel-zinc-copper-cobalt deposit in Finland was discovered in 1977 and intermittently explored by Outokumpu from 1978 through 2004. Talvivaara Mining Company plc acquired the rights to mine the property in 2004, and the mine initiated operations in late 2008. Technological problems related to the crushing circuit have limited production so that a production level of $1,200 \mathrm{t} / \mathrm{yr}$ of cobalt in nickel-cobalt sulfide was expected by 2012 ; expansion to $1,800 \mathrm{t} / \mathrm{yr}$ of cobalt was possible by 2013 (Talvivaara Mining Company, 2009). The Kylylahti copper-cobalt-nickel sulfide deposit in Finland was discovered in 1984 and intermittently explored by Outokumpu from 1984 through 1994. Vulcan Resources Limited acquired the property in 2004 and conducted extensive exploration prior to preparing a feasibility study in 2008 modeled on a plant capacity that included 1,900 $\mathrm{t} / \mathrm{yr}$ of cobalt contained in concentrate (Vulcan Resources Limited, 2008). In 2008, the project was fully permitted but development was suspended because of depressed metal prices and financial markets (Vulcan Resources Limited, 2009).

The Caldag nickel-cobalt laterite deposit in Turkey was discovered in the late 1970s, but was not extensively explored until 2002 when European Nickel plc acquired an option to develop the deposit. The project was in the permitting and financing stage. Development plans called for the recovery of $1,000 \mathrm{t} / \mathrm{yr}$ of cobalt as a mixed nickel-cobalt hydroxide product beginning in 2011 (European Nickel plc, 2009).

\section{Factors Affecting Cobalt Supply}

Many factors, including capital and operating costs, commodity prices, corporate finances, economic conditions, exchange rates, government policies, real and perceived risk factors, and tax structures, influence the timing and magnitude of the development of potential supply. The percentage of global cobalt supply that is attributed to selected mines that began or significantly expanded operations from 1995 through 2009 is shown in figure 3 . The selected mines each had a design capacity equal to or greater than 1,000 t/yr of cobalt. The chart shows the actual contribution of these mines as a percentage of total global cobalt mine production, as reported by USGS sources (U.S. Geological Survey Minerals Yearbook series, various authors, countries, and years). Data shown in figure 3 relate annual changes in supply from 1995 through 2009 to changes in annual commodity prices for cobalt, copper, and nickel relative to historical averages for the study period, as well as other significant events affecting the cobalt market. In general, new mines were brought into production during or following sustained periods of higher commodity prices. Development of mines with significant copper or nickel reserves coincided with periods of higher copper or nickel prices, even when the price of cobalt was relatively low, because cobalt revenues were not as critical to profit margins as copper or nickel. A large increase in cobalt supply occurred between 2005 and 2007, primarily from new mine production

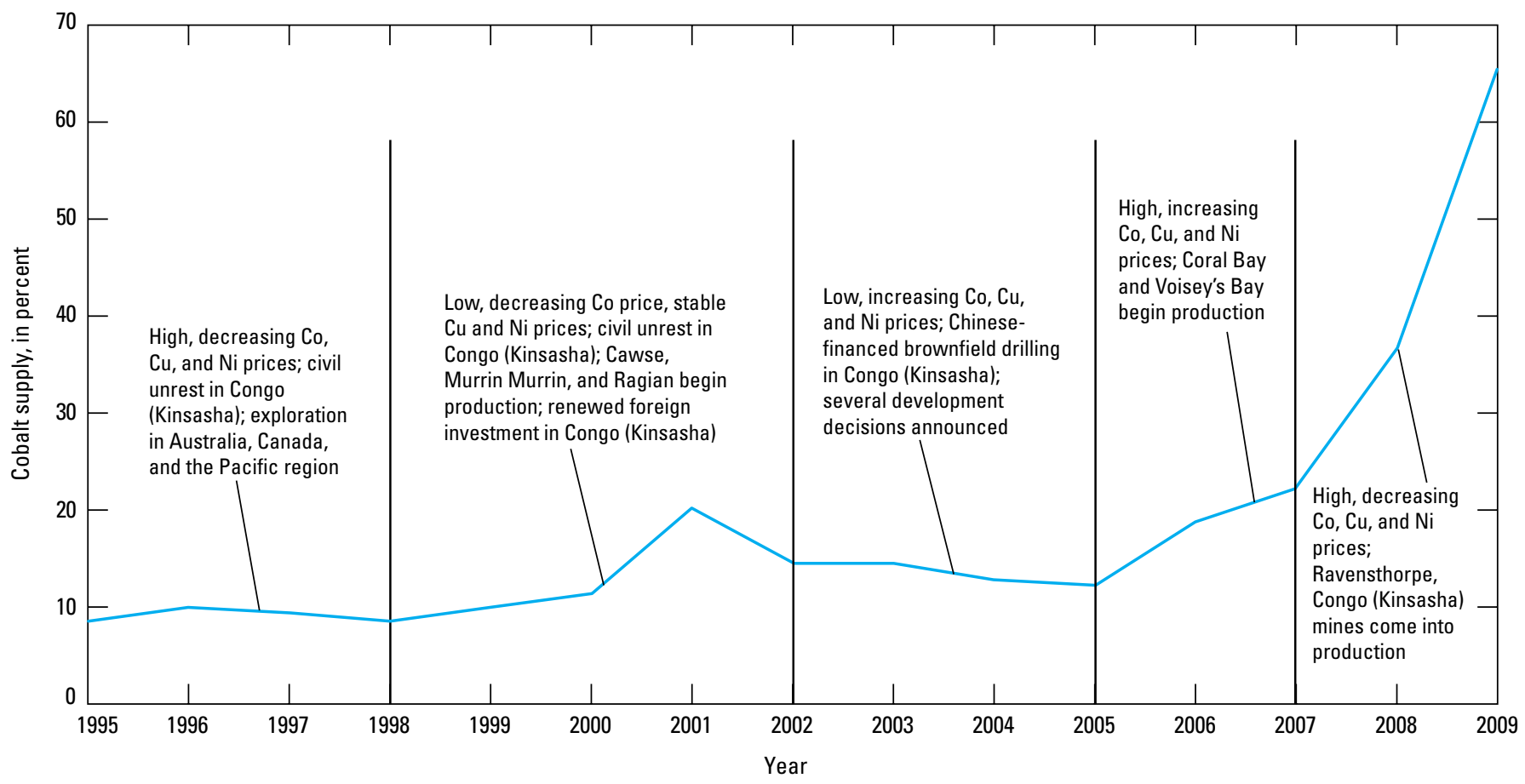

Figure 3. Percentage of total cobalt supply from selected new or expanding mines from 1995 through 2008, as related to global events. Graph shows cumulative production derived from selected new or expanding mining operations as a percentage of total global production for each specified year. In 1995, global production was estimated by the U.S. Geological Survey as 24,500 metric tons of cobalt; in 2008 , global cobalt production was estimated as 75,900 metric tons of cobalt. Site data do not include production from producers with no new capacity or sites producing less than 1,000 metric tons per year of contained cobalt. Source: Percentage values were derived from reported company site production data and global production data reported by the U.S. Geological Survey, Minerals Yearbook series, various authors and various years. Co, cobalt; $\mathrm{Cu}$, copper; $\mathrm{Ni}$, nickel. 
that became operational in Canada and the Philippines, and after 2007 when operations commenced in Australia and Congo (Kinshasa). Although higher commodity prices increased the revenue from these new production sources of cobalt in 2007 and part of 2008, lower metal prices and the decreased consumption in late 2008 resulted in a surplus of cobalt supply, as global consumption could not keep pace with increased supply.

A weakening in the global economy that began in late 2008 resulted in lower demand for many metals, including cobalt, and reduced global production. Many previously announced mine developments and expansions were suspended, scaled back, or delayed until such time as market prices could justify further investment or capital expenditure, and some mine production was curtailed. A few projects (such as Kamoto, Mukondo Mountain, and Ruashi) have maintained their development schedules to meet supply obligations and are expected to contribute toward cobalt supply as shown in figures 3,4 , and 5 . The installed cobalt capacity from new operations possibly would be higher in 2013 had the global economy been stronger in 2008 and 2009.

The reduction in global copper and cobalt consumption in late 2008 occurred along with a reported increase in exports from Congo (Kinshasa) to China (Xu and Yang, 2009). China imported large quantities of copper-cobalt ore, concentrate, and intermediate products in 2008 , but because of the global economic recession, much of these imports were not immediately processed, resulting in a considerable stockpile of materials containing copper and cobalt in China at the beginning of 2009 (Taarland, 2009; Xu and Yang, 2009).
Deposit geology, process technology, and relative values of recoverable products are other factors that must be considered when assessing project viability as related to cobalt supply. Changes in capacity or production of associated metals, particularly the principal metal, affect the amount of cobalt that is available in any given year. Because much of the world's cobalt is recovered as a byproduct of copper or nickel, the quantity of cobalt produced is often dependent on the commercial viability of producing the primary commodities. Cobalt production as a byproduct of nickel operations has increased between 1995 and 2007 with the development of several large nickel laterite projects in Australia and the Pacific region. Between March and November 2008, however, the price of nickel declined from $\$ 15$ per pound to about $\$ 4$ per pound, resulting in the suspension of about 30 percent of global nickel production capacity and the cessation of development activities at other operations. Consequently, byproduct cobalt production from nickel operations was affected by the suspension or closure of nickel mines during this period.

Cobalt has been produced as a principal product from concentrates and tailings in Morocco for many years. Through 2013, plans for projects where cobalt is the principal product were proceeding in Cameroon, Congo (Kinshasa), the United States, and Zambia. The quantity of anticipated new cobalt design capacity for 2009 through 2013, attributed by the principal commodity produced, is summarized in figure 4 . If all projects are developed according to planned schedules by 2013, nickel projects would account for about 38 percent of the new cobalt capacity, copper projects would account for

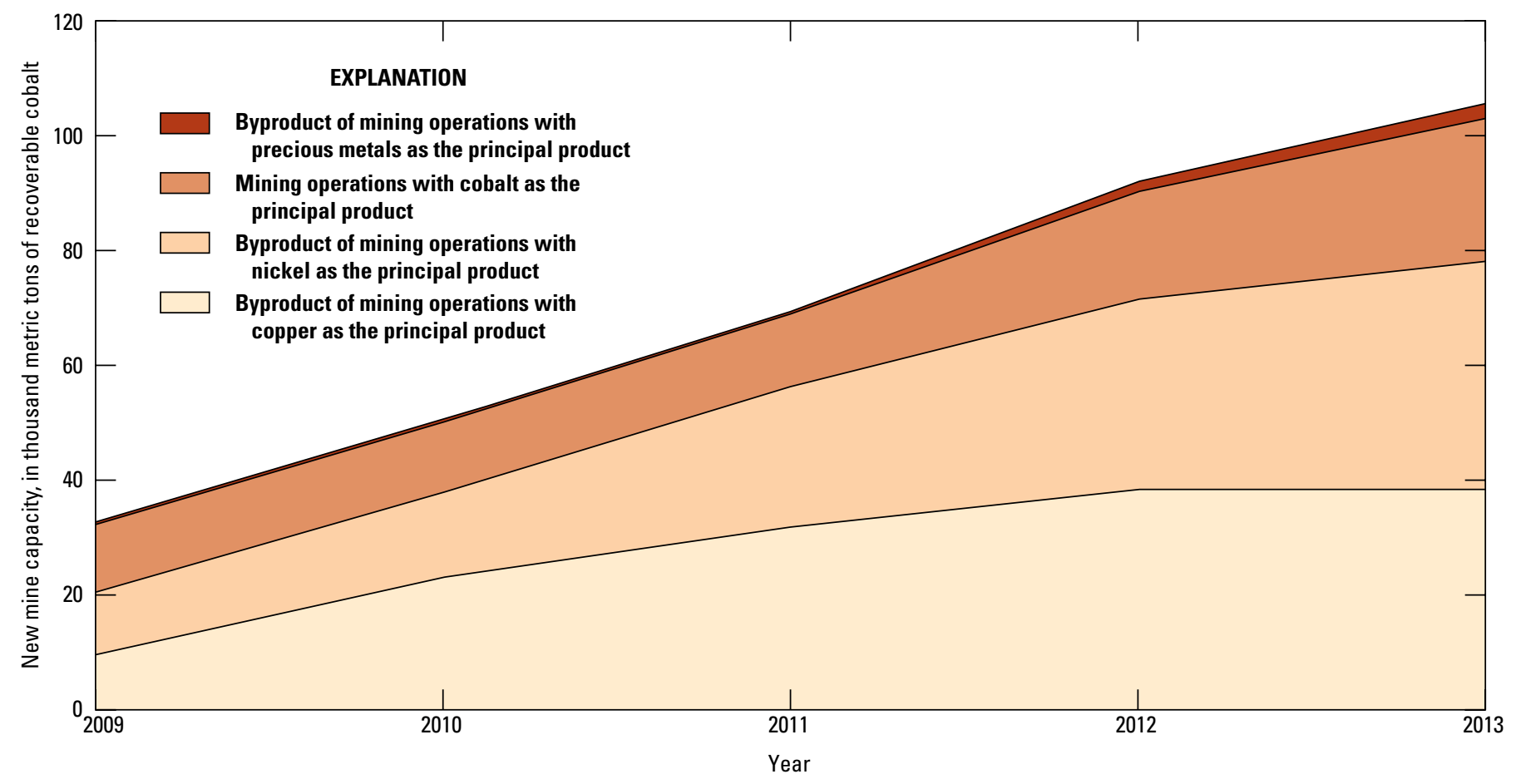

Figure 4. Anticipated new cobalt capacity from 2009 through 2013 from selected sites attributed to principal commodity. Selected sites exceed an annual capacity of 1,000 metric tons per year of contained cobalt. Calculations represent recoverable cobalt content of ores, concentrates, or intermediate products. Industry reported development schedules and design capacities were used in this analysis. 


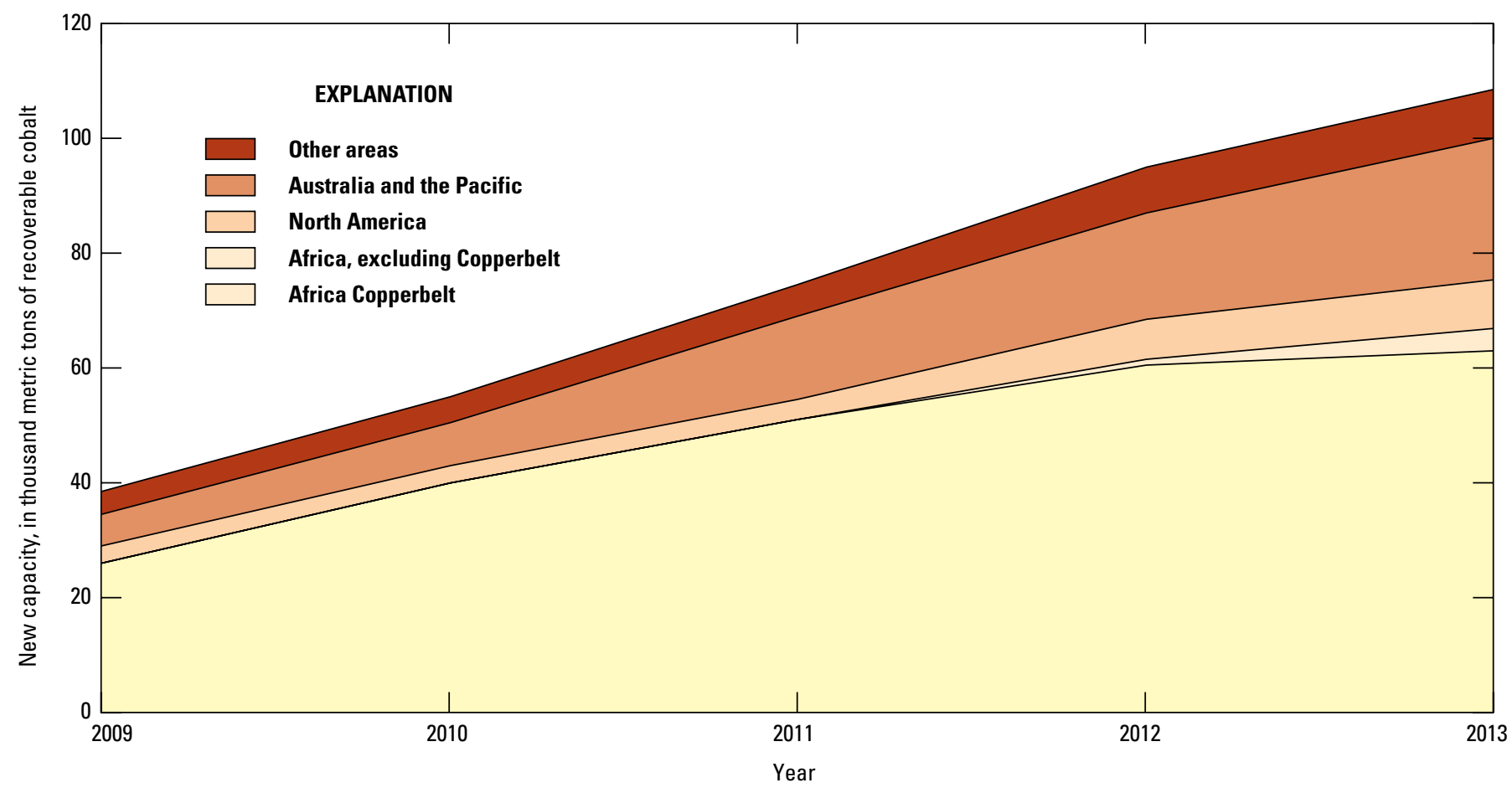

Figure 5. Anticipated new cobalt capacity from 2009 through 2013 from selected sites by region. Selected sites exceed an annual capacity of 1,000 metric tons per year of contained cobalt. Calculations represent recoverable cobalt content of ores, concentrates, or intermediate products from mining operations. Industry reported development schedules and planned capacities were used in this analysis.

about 36 percent, and projects where cobalt was the principal product would account for 24 percent of new global capacity.

Ore chemistry and available process technology also are important considerations in mine development decisions. In 1995, about 39 percent of nickel production was derived from laterites and 61 percent from sulfides (Davidson, 2006). Since the Voisey's Bay project came into production in late 2005, no new world-class nickel sulfide deposits containing recoverable cobalt were actively being developed. CRU Group Limited estimated (prior to the decline in nickel price in 2008) that about 54 percent of nickel production would come from laterites by 2010 . About 67 percent of the nickel capacity derived from laterites is dependent on high-pressure acid leach technology (Davidson, 2006). For some new operations, this technology has proven to be technologically complex and operationally demanding, occasionally causing delays in plant startup. Because this analysis has relied on company development schedules for new capacity estimates, any changes in schedule or capacity as a result of mining or processing delays that have not yet occurred will likely reduce global capacity estimates developed in this study.

Social and political conditions influence mine development and production. Changes to the mining industry in Congo (Kinshasa) between 1995 and the present illustrate this point. From 1995 through 2002, civil unrest limited mining in Congo (Kinshasa). Even after a peace accord and a revised mining code were signed in 2002, sporadic fighting has made mining for cobalt and copper in Congo (Kinshasa) difficult. Fighting had weakened the domestic economy, and extensive infrastructure improvements were needed. To meet the needs of a growing Chinese economy and to strengthen their economic position in the global economy, Chinese companies interested in securing supplies of copper and cobalt increased their involvement in the mining sector of Congo (Kinshasa) since 2002 by expanding ownership in mines and processing facilities in Congo (Kinshasa), investing in regional infrastructure, and developing supply contracts. The 2007 ban on the export of unprocessed cobalt ores and cobalt concentrates from Congo (Kinshasa) imposed by the Congolese Government reduced Chinese refined cobalt production during the year. The 2008 multibillion dollar trade agreement that would provide China with a specified amount of copper and cobalt as ore, concentrate, intermediate products, and refined metal in exchange for funds to improve local infrastructure (Whewell, 2009) may reduce the likelihood of future supply disruptions in China from Congo (Kinshasa). A similar $\$ 3.6$ billion agreement was signed in July 2009 between Zambia and Chinese interests for Chinese mining investment in Zambia (Zambia Development Agency, 2009). China was also seeking to strengthen its supply position for such strategic minerals as copper and cobalt in other regions of the world, particularly those areas with short, direct supply routes to China, such as Australia and Southeast Asia.

Estimates for the amount of cobalt that could be recovered by region if the sites selected for this analysis were to begin production as designed and scheduled from 2009 through 2013 are shown in figure 5. In 2009, 77 percent of the anticipated new cobalt mine capacity would occur in the African Copperbelt countries of Congo (Kinshasa) and Zambia. By 2013, about 40 percent of new capacity was expected to come from the African Copperbelt; 38 percent, from Australia and the South Pacific countries of Philippines, 
Indonesia, New Caledonia, and Papua New Guinea; 11 percent, from other African countries; 5 percent, from North America; and 6 percent, from other areas. This distribution is not surprising given the active participation of Chinese interests in developing sources of cobalt from Africa and Australasia.

\section{Summary and Conclusions}

Many factors determine whether or not a specific mineral deposit will be developed into a mine and the timing associated with that development. The geologic characteristics of the resource determine the resource's extent, quality of mineralization, and recoverability. Once a resource has been adequately defined, a combination of external factors influences site development. Although the factors influencing the decision to develop each project are often different, some general conclusions can be drawn from this analysis, based on ongoing USGS monitoring of global mineral activities. This analysis was based on development plans reported as of May 2010; any subsequent changes would affect the results of this study.

Much of the cobalt supply is derived as a byproduct of copper and nickel mining. Consequently, economic, environmental, political, and technological factors affecting copper and nickel exploration and production may also affect cobalt supply.

In 2006, about 40 percent of the cobalt produced globally was derived from artisanal mining and copper-cobalt ores from Congo (Kinshasa), using more conventional large-scale mining and processing methods. However, the estimated capacity utilization of facilities producing cobalt from Congo (Kinshasa) in 2008 was estimated to be about 22 percent. The capacity for some facilities is likely to have been overreported. Future cobalt production from Congo (Kinshasa) may increase if financing, infrastructure, and economic markets improve. Therefore, future economic, political, and social conditions in Congo (Kinshasa) are likely to affect future cobalt supply.

The development of cobalt-rich nickel laterite deposits in Australia and the South Pacific, as well as improvements in laterite processing technology, occurred at a time when mining of copper-cobalt deposits in Congo (Kinshasa) was limited because of regional conflict.

Between 1995 and 2008, there was increased reliance on cobalt as a byproduct of nickel mining in Australia and Canada.

Exploration programs and (or) technological improvements have improved the likelihood of the development of new cobalt capacity in Cameroon, Congo (Kinshasa), and the United States.

The emergence of China as a major producer and consumer of refined cobalt, primarily for rechargeable batteries, has increased that country's demand for cobalt raw materials, particularly from Africa and Australasia.

Chinese companies are increasingly becoming involved in copper-cobalt exploration and mining in Congo (Kinshasa) and Zambia in addition to nickel-cobalt mining in Australia, the South Pacific, and elsewhere. Chinese-financed infrastructure improvements in the Copperbelt of Africa could increase capacity utilization of existing operations and stimulate the creation of new capacity.

Higher metal prices between 2005 and early 2008 encouraged the exploration, planning, and development of many new copper-cobalt and nickel-cobalt projects. The global economic recession that began in late 2008, however, caused much of this development activity to be suspended, deferred, or cancelled.

More than 100,000 $t$ of installed cobalt capacity would likely be added from 2009 through 2013 from the projects considered in this analysis, if all sites came into production as scheduled.

Projects where nickel, copper, and cobalt are the principal metals would contribute about 38,36 , and 24 percent, respectively, of the additional global cobalt supply in 2013.

In 2013, about 58 percent of expanded production was expected to come from the African Copperbelt; 23 percent, from Australia and the South Pacific countries of Philippines, Indonesia, New Caledonia, and Papua New Guinea; 7 percent, from North America; 4 percent, from other African countries; and 8 percent from other areas.

\section{References Cited}

Baja Mining Corporation, 2010, Baja confirms robust economics at Boleo: Baja Mining Corporation press release, January 15, accessed August 12, 2009, at http://www.bajamining.com/_ resources/news/pr_2010_01_15.Baja.Confirms.Robust. Economics.at.Boleo.pdf.

BHP Billiton Limited, 2008, Australian site tour Ravensthorpe nickel operation: BHP Billiton Limited presentation, accessed September 2, 2009, at http://www.bhpbilliton.com/bbContent/Repository/docs/ ravensthorpeSitePresentation08.pdf.

Caledonia Mining Corporation, 2008, Caledonia update on operations: Caledonia Mining Corporation press release, October 23, accessed October 23, 2008, at http://www.investigate.co.uk/ articlePrint.aspx?id=20081023135433M1077.

Central African Mining and Exploration Company, plc, 2009a, Cobalt operations recommence at Mukondo Mountain: Central African Mining and Exploration Company, plc press release, March 26, accessed March 27, 2009, at http://investigate.co.uk/articlePrint. aspx?id=200903260700114908P.

Central African Mining and Exploration Company, plc, 2009b, Success on purpose: Central African Mining and Exploration Company, plc corporate presentation, August 3, 35 p., accessed August 10, 2009, at http:/www.camec-plc.com/ financial-presentations/.

Coakley, G.J., 2003, The mineral industry of Congo (Kinshasa), in Area reports: International-Africa and the Middle East: U.S. Geological Survey Minerals Yearbook 2002, v. III, p. 10.1-10.9. (Also available at http://minerals.usgs.gov/minerals/pubs/country/2002/ cgmyb02.pdf.) 
Coakley, G.J., 2004, The mineral industry of Congo (Kinshasa), in Area reports: International-Africa and the Middle East: U.S. Geological Survey Minerals Yearbook 2003, v. III, p. 10.1-10.8. (Also available at http://minerals.usgs.gov/minerals/pubs/country/2003/ cgmyb03.pdf.)

Cobalt Development Institute, 2008, Cobalt supply and demand 2009, in Cobalt facts: Cobalt Development Institute, p. 53-58, accessed June 17, 2010, at http://www.thecdi.com/cobaltfacts.php.

Companhia Vale do Rio Doce, 2009a, Form 20-F for the fiscal year ending December 31, 2008: Companhia Vale do Rio Doce, April 28, 217 p., accessed September 15, 2009, at http://www.vale.com/cale_us/media/20F_2008_i.pdf.

Companhia Vale do Rio Doce, 2009b, Vale says acid spilled at New Caledonia project: Companhia Vale do Rio Doce press release, April 7, accessed September 3, 2009, at http://www.reuters.com/article/2009/04/07/ vale-spill-idUS0749098920090407.

Compass Resources NL, 2009, Mining Browns oxide project: Compass Resources NL, Accessed September 3, 2009, at http://www.compassnl.com.au/ mining_browns_oxide_project.htm.

Davidson, Vanessa, 2006, Nickel market overview-The supply response: International Nickel Study Group Conference, October 2006, Presentation, 27 slides.

Eramet SA, 2009, Doniambo Smelter: Eramet SA, accessed August 28, 2009, at http://www.eramet.fr/us/production_gallery_content/Documents/Nos_metiers/Nickel/UK/ Doniambo_UK7.pdf.

European Nickel plc, 2009, Investor presentation: European Nickel plc, March, accessed September 14, 2009, at http://www.enickel.co.uk/_data/assets/pdf_file/0011/71669/ ENK_Presentation_March_2009.pdf.

First Quantum Minerals Limited, 2008, Kolwezi fact sheet: First Quantum Minerals Limited, accessed August 11, 2009, at http://www.first- quantum.com/i/pdf/ KolweziFactSheet2008.pdf.

Formation Capital Corporation, 2010, Formation begins construction of Idaho cobalt project: Formation Capital Corporation press release, February 25, accessed June 16, 2010, at http://www.formationmetals.com/s/ News.asp?ReportID=386610.

Fortune Minerals Limited, 2009, Fortune Minerals announces pilot plant hydrometallurgical results for the Nico goldcobalt-bismuth-copper deposit: Fortune Minerals Limited press release, February 24, accessed August 12, 2009, at http://www.fortuneminerals.com/s/NewsReleases. asp?printVersion $=$ now\&_Title $=$ Fortune-Announces-PilotPlant-Hydrometallurgey-Results-For-The-Nico-GoldCobalt-Bismuth-Copper-Deposit\&ReportID=339275.

Freeport-McMoRan Copper \& Gold, Incorporated, 2009, Freeport-McMoRan Copper \& Gold, Inc. reports secondquarter and six-month 2009 results: Freeport-McMoRan Copper \& Gold, Incorporated, accessed August 11, 2009, at http://www.fcx.com/news/2009/072109.pdf.
George Forrest International S.A., 2007, Production base: George Forrest International S.A. press release, January 30, accessed August 27, 2009, at http://www.forrestgroup.com/ fr/chap06/infos 42. html.

Geovic Mining Corporation, 2009, Annual shareholder meeting operations update, June 2009: Geovic Mining Corporation, accessed September 2, 2009, at http://www.geovic.net/userfiles/file/corporate presentations/09-06-15\%20Annual $\% 20$ Shareholders\%20Meeting\%20Operations\%20Update $\% 20$ -\%20Final.pdf.

Gladstone Pacific Nickel Limited, 2009, Lapse of MoU with MCC: Gladstone Pacific Nickel Limited press release, June 30, accessed August 12, 2009, at http://www.gladstonepacific.com.au/index. php src $=$ news \&prid $=208 \&$ category $=$ news $\% 202009$.

Glencore International AG, 2009, Murrin Murrin: Glencore International AG, accessed September 8, 2009, at http://www.glencore.com/pages/a_murrin.htm.

Highlands Pacific Limited, 2009, Update-Ramu nickel: Highlands Pacific Limited press release, July 28, accessed August 12, 2009, at http://www.highlandspacific.com/pdf/ Ramu_Update_July.pdf.

Hill, Liezel, 2009, Global output of refined cobalt rose 4.1 percent last year: Creamer Media's Mining Weekly, April 8, accessed July 27, 2009, at http://www.miningweekly.com/article/global-output-ofrefined-cobalt-rose-41-last-year-2009-04-08.

International Monetary Fund, 2005, Democratic Republic of the Congo-Selected issues and statistical appendix: Washington, DC, International Monetary Fund, 97 p., accessed September 14, 2009, at http://www.imf.org/external/pubs/ft/ scr/2005/cr05373.pdf.

Katanga Mining Limited, 2008, Creating a leading African copper and cobalt company: Katanga Mining Limited presentation, November 7, accessed August 11, 2009, at http://www.katangamining.com/kat/investor_relations/presentations/pre2008/3q_pro/3q_pro.pdf.

Dixon, Roger, Simposya, Victor, Takolia, Ebrahim, Waldeck, Wally, Salter, Henrietta, von Wielligh, Anton, Naismith, Alan, Cilliers, Petrus, and McNeill, Rob, 2009, An independent technical report on the material assets of Katanga Mining Limited, Katanga province, Democratic Republic of Congo: Katanga Mining Limited SRK Consulting project no. 389772, 213 p., accessed July 27, 2009, at http://www.investis.com/kat/ operations/reportsoperational/techreport-mar09.pdf.

MetalMiner, 2009, Cobalt—Strategic and in short supply, part one: MetalMiner, accessed July 27, 2009, at http://agmetalminer.com/2009/03/02/cobalt-strategic-andin-short-supply-part-one/.

MetalPrices.com, 2009, Metal prices and news on the internet: MetalPrices.com, accessed August 17, 2009, at http://www.metalprices.com/FreeSite/index.asp.

Metorex Limited, 2009, Operations-Ruashi Mining SPRLCopper and cobalt: Metorex Limited, accessed August 11, 2009, at http://www.metorexgroup.com/ops_Ruashi_ Mining_sprl.htm. 
MMC Norilsk Nickel, 2009, Cawse: MMC Norilsk Nickel, accessed August 26, 2009, at http://www.nornik.ru/en/ our_products/norilsknickelaustralia.

Peterson, J.S., 2009, Mindoro nickel-Development in a new global setting: Asia Mining Congress, 5, Oslo, Norway, March 25, 2009, Presentation, 21 slides, accessed August 21, 2009, at http://www.intexresources.com/_upl/intex resources_-_asia_mining_congress_march_2009.pdf.

Reuters, 2009, China's CNMC to invest $\$ 400 \mathrm{M}$ in Zambia mines: Bear Dolbear global mining news, no. 258 , June 15 , p. 2 ., accessed September 14, 2009, at http:/www.dolbear.com/Newsletter/ GlobalMiningIssue258Jun1509.pdf.

Shedd, K.B., 1999-2010, Cobalt, in Metals and minerals: U.S. Geological Survey Minerals Yearbook 1995-2008, v. I, [variously paged], accessed July 27, 2009, at http://minerals.er.usgs.gov/minerals/pubs/commodity/ cobalt/.

Shedd, K.B., 2009a, Cobalt in January, February, and March 2008: U.S. Geological Survey Mineral Industry Surveys, January, accessed July 27, 2009, at http://minerals.er.usgs.gov/minerals/pubs/commodity/ cobalt/mis-200801_02_03-cobal.xls.

Shedd, K.B., 2009b, Cobalt, in Metals and minerals: U.S. Geological Survey Minerals Yearbook 2007, v. I, p. 19.1-19.23, accessed July 27, 2009, at http://minerals.er.usgs.gov/minerals/pubs/commodity/ cobalt/myb1-2007-cobal.pdf.

Shedd, K.B., 2009c, Cobalt in October, November, and December 2008: U.S. Geological Survey Mineral Industry Surveys, April, accessed July 27, 2009, at http://minerals.er.usgs.gov/minerals/pubs/commodity/ cobalt/mis-200810_11_12-cobal.pdf.

Shedd, K.B., 2009d, Cobalt: U.S. Geological Survey Mineral Commodity Summaries 2009, p. 48-49. (Also available at http://minerals.er.usgs.gov/minerals/pubs/commodity/ cobalt/mcs-2009- cobal.pdf.)

Shedd, K.B., 2010a, Cobalt, in Metals and minerals: U.S. Geological Survey Minerals Yearbook 2008, v. I, p. 19.1-19.24, accessed July 27, 2009, at http://minerals.er.usgs.gov/ minerals/pubs/commodity/cobalt/myb1-2008-cobal.pdf.

Shedd, K.B., 2010b, Cobalt: U.S. Geological Survey Mineral Commodity Summaries 2010, p. 46-47. (Also available at http://minerals.er.usgs.gov/minerals/pubs/commodity/ cobalt/mcs-2010-cobal.pdf.)

Sherritt International Corporation, 2009a, 2008 annual report-Management discussion and analysis and financial statements: Sherritt International Corporation, 104 p., accessed September 14, 2009, at http://www.sherritt.com/ doc08/files/financials/2008\%20Annual\%20Report/Sherritt_AR08_mdafs.pdf.

Sherritt International Corporation, 2009b, Sherritt and Ambatovy partners finalize arrangements for remaining funding for the Ambatovy project: Sherritt International Corporation press release, June 29, 2009, p. 2, accessed
June 30, 2009, at http:/www.sherritt.com/doc08/files/ newsroom/2009-06-24\%20Ambatovy \%20Financing\%20 Press\%20Release\%20-\%20Final.pdf.

Sumitomo Metal Mining Company Limited, 2009, Annual report 2009: Sumitomo Metal Mining Company Limited, 102 p., accessed September 14, 2009, at http://www.smm.co.jp/E/ir/library/annual-report/pdf/ AR2009e.pdf.

Taarland, Eric, 2009, The outlook for cobalt: Cobalt Development Institute Conference, Lisbon, Portugal, May 13-14, 2009, Presentation.

Talvivaara Mining Company, 2009, Proposed placing and trading: Talvivaara Mining Company press release, accessed July 27, 2009, at http://www.talvivaara.com/media-en/ media-releases/stock_exchange_releases.

Vulcan Resources Limited, 2008, Vulcan to proceed with Kylylahti mine: Vulcan Resources Limited press release, April 14, 2008, p. 2, available at http:/www.vulcanresources.com.au/aurora/assets/ user_content/File/VRL1548D-AC\%20(FINAL\%20 14Apr08).pdf.

Vulcan Resources Limited, 2009, About Vulcan: Vulcan Resources Limited, accessed August 12, 2009, at http://www.vulcanresources.com/au/home.1.html.

Whewell, Tim, 2008, China to seal \$9bn DR Congo deal: BBC News, accessed July 27, 2009, at http://news.bbc.co.uk/go/ $\mathrm{pr} / \mathrm{fr} /-/ 2 /$ hi/programmes/newsnight/7343060.stm.

Xstrata plc, 2007, Raglan expansion study commencesExceptional exploration results: Xstrata plc press release, August 7, accessed September 14, 2009, at http://www.xstrata.com/media/news/2007/08/07/0702CET/ 200708070702.en.pdf.

Xu, Aidong, and Yang, Xiaofei, 2009, Analysis of China cobalt market: Cobalt Development Institute Conference, Lisbon, Portugal, May 13-14, 2009, Presentation.

Yager, T.R., 2008, The mineral industry of Congo (Kinshasa), in Area reports: International-Africa and the Middle East: U.S. Geological Survey Minerals Yearbook 2006, v. III, p. 11.1-11.7. (Also available at http://minerals.usgs.gov/ minerals/pubs/country/2006/myb3-2006-cg.pdf.)

Yager, T.R., 2009, The mineral industry of Congo (Kinshasa), in Area reports: International-Africa and the Middle East: U.S. Geological Survey Minerals Yearbook 2007, v. III, p. 1.1-11.8. (Also available at http://minerals.usgs.gov/minerals/pubs/country/2007/myb3-2007-cg.pdf.)

Yager, T.R., 2010, The mineral industry of Congo (Kinshasa), in Area reports: International-Africa and the Middle East: U.S. Geological Survey Minerals Yearbook 2008, v. III, p. 11.1-11.8. (Also available at http://minerals.usgs.gov/ minerals/pubs/country/2007/myb3-2007-cg.pdf.)

Zambia Development Agency, 2009, Chinese firm to invest in Zambia: Zambia Development Agency, accessed August 19, 2009, at http://www.zda.org.zm/212-chinese-firm-invest-zambia. 
Manuscript approved on June 7, 2011.

Prepared by the Pembroke, Reston, and Fort Lauderdale Publishing Service Centers.

Edited by Anna N. Glover and Jane Eggleston.

Graphics by Anna N. Glover and Ron Spencer.

Design and typography by Anna N. Glover.

Web support by Sue Bergin.

For more information concerning the research in this report, contact

David R. Wilburn

U.S. Geological Survey

Box 25046

Denver Federal Center

Mail Stop 750

Denver, C0 80225-0046

Telephone: (303) 236-5213 
